Volume 7

Number 1 Fall 2019 Symposium Edition

Pharmaceutical Innovation, Patent Protection,

Article 2 and Regulatory Exclusivities

2-9-2021

\title{
Is Biopharma Ready for the Standard Wars?
}

Jorge L. Contreras

S.J. Quinney College of Law, University of Utah, jorge.contreras@law.utah.edu

Follow this and additional works at: https://scholarship.law.tamu.edu/journal-of-property-law

Part of the Antitrust and Trade Regulation Commons

\section{Recommended Citation}

Jorge L. Contreras, Is Biopharma Ready for the Standard Wars?, 7 Tex. A\&M J. Prop. L. 43 (2021). Available at: https://doi.org/10.37419/JPL.V7.I1.2

This Symposia Article is brought to you for free and open access by Texas A\&M Law Scholarship. It has been accepted for inclusion in Texas A\&M Journal of Property Law by an authorized editor of Texas A\&M Law Scholarship. For more information, please contact aretteen@law.tamu.edu. 


\title{
IS BIOPHARMA READY FOR THE STANDARDS WARS?
}

\author{
Jorge L. Contreras ${ }^{\dagger}$
}

\begin{abstract}
This symposium contribution sheds new light on Momenta v. Amphastar, a case in which issues relating to standardization and patent disclosure that have previously been observed in the semiconductor, computing, and telecommunications sectors found their way into a dispute between two biosimilar manufacturers. One such manufacturer, Momenta, participated in the development of a standard for testing the purity of generic enoxaparin under the auspices of the United States Pharmacopeial Convention but failed to disclose that it had applied for a patent on the testing method. When Momenta later sued Amphastar for patent infringement by using the method in accordance with the FDA's approval of its own generic version of enoxaparin, Amphastar raised waiver and equitable estoppel as defenses, then brought antitrust claims against Momenta and its distribution partner Sandoz. Amphastar prevailed at the district court, obtaining a ruling that Momenta's patent was unenforceable. This case demonstrates that issues surrounding the acquisition and disclosure of patents on standardized technologies have more salience in the biopharma sector than commonly believed. As such, standards organizations operating in this sector should ensure that their policies and procedures are robust enough to delineate clearly the obligations of participants with respect to patents covering standardized technologies, and organizations that participate in biopharma standards-development should heed the
\end{abstract}

DOI: https://doi.org/10.37419/JPL.V7.I1.2

$\dagger$ Presidential Scholar and Professor of Law, University of Utah S.J. Quinney College of Law, Adjunct Professor, Department of Human Genetics, University of Utah School of Medicine. This research was made possible in part through generous support from the Huntsman Cancer Institute. This paper has benefitted from discussion and feedback at the Texas A\&M School of Law Symposium on Pharmaceutical Innovation, Patent Protection and Regulatory Exclusivities (Oct. 2019). Comments and feedback by Jacob Sherkow and research assistance by Sydney Hecimovich are greatly appreciated. 
valuable lessons offered by more than three decades of litigation and policy making in the technology sector.

I. INTRODUCTION 44

II. STANDARDS AND PATENTS 46

A. Policies of Standards Development Organizations ............. 46

B. Standards Deception as a Defense to Infringement of SEPS 48

C. Antitrust Remedies for Standards Deception.................... 50

III. THE ENOXAPARIN CONTROVERSY: A BIOPHARMA STANDARDS

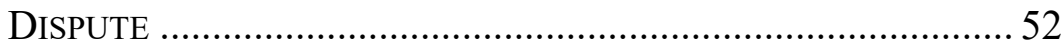

A. Enoxaparin-Approval and Market Entry ...................... 52

B. The USP and Method 207.............................................. 54

C. The USP Policies ........................................................... 57

D. Participant Understandings of USP's Disclosure

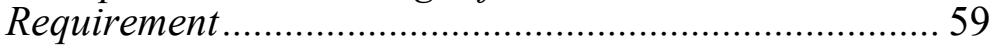

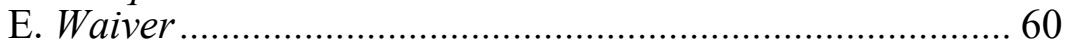

F. Equitable Estoppel .................................................. 61

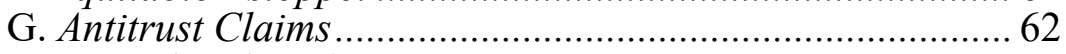

H. Appeal and Settlement ..................................................... 63

IV. IMPLICATIONS OF MOMENTA V. AMPHASTAR-HOW WILL

BIOPHARMA FARE IN THE STANDARDS WARS? ....................... 64

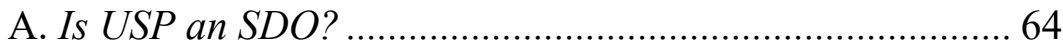

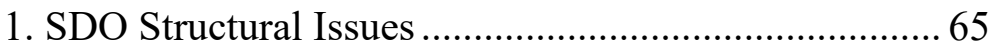

2. Nature of the Standards................................................6 66

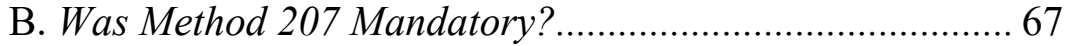

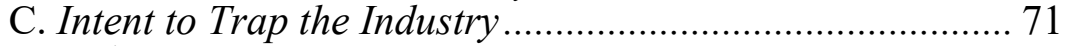

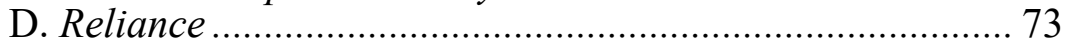

E. Antitrust Claims ............................................................. 75

F. The Need for Clarity in Biopharma SDO Policies............. 77

V. CONCLUSION.

\section{INTRODUCTION}

In 2011, Momenta Pharmaceuticals, the manufacturer of a generic biosimilar version of the best-selling anticoagulant enoxaparin, sued another generic enoxaparin manufacturer, Amphastar Pharmaceuticals, for patent infringement. The asserted patent (U.S. Patent No. 7,575,886 (the " 886 Patent")) did not claim a chemical structure or attribute of the drug but a quality control process used in its manufacture. The process, known as "Method 207", was developed at the United States Pharmacopeial Convention ("USP"), 
the body responsible for setting many drug-related standards in the United States. According to Amphastar, USP's internal policies required participants in the development of USP standards to disclose patents and patent applications covering proposed USP standards. Though at least one Momenta researcher was involved in the development of Method 207, Momenta failed to disclose the ' 886 Patent prior to USP's approval of Method 207. Amphastar then used Method 207 in the production of generic enoxaparin, allegedly pursuant to U.S. Food and Drug Administration ("FDA") requirements. ${ }^{1}$ When Momenta sued Amphastar for infringement of the '886 Patent, Amphastar argued that by failing to comply with USP's patent disclosure requirements, Momenta waived its right to enforce the patent, was estopped from doing so, and that any such enforcement constituted attempted monopolization in violation of Section 2 of the Sherman Act.

Contentions such as these have been made for decades in the computing, networking, telecommunications, and semiconductor industries (generally lumped together as "information and communications technology" or "ICT"), which depend heavily on industry standards. ${ }^{2}$ Litigation over the disclosure and non-disclosure of patents essential to industry standards (standards-essential patents or "SEP"s) has included both private claims and enforcement actions by governmental agencies in the U.S. and abroad. The aggregate of these disputes has colloquially been termed the global "standards wars." 3 But while a range of industry standards have been developed for biotechnology and pharmaceutical applications,${ }^{4}$ few of them have resulted in disputes relating to patents. Momenta v. Amphastar is

1. Complaint at 12, Amphastar Pharm., Inc. v. Momenta Pharm., Inc. (C.D. Cal. 2017) (No. 5:15-cv-01914) [hereinafter Complaint I].

2. There are a few notable exceptions, including the FTC's case against Unocal with respect to a standard for gasoline additives. See discussion infra Part III.A.

3. See, e.g., Jorge L. Contreras, The Global Standards Wars: Patent and Competition Disputes in North America, Europe and Asia, KEIO U. J.L. POLS. \& SOC. (2018), https://papers.ssrn.com/sol3/papers.cfm?abstract_id=3106090 [https://perma.cc/ZB42-TNZV].

4. See, e.g., Jorge L. CONTRERAS \& ADriAn ThOROGOOD, Technical Standards for Bioinformatics and Medical Informatics, in BIOINFORMATICS, MEDICAL INFORMATICS AND THE LAw (Jorge L. Contreras, A. James Cuticchia, \& Gregory Kirsch, eds., Edward https://papers.ssrn.com/sol3/papers.cfm?abstract_id=3665429

[https://perma.cc/7L6U-UP5V] (forthcoming 2011) (describing a range of standards in the fields of genetics, genomics and computational biology). 
notable, if not unique, in that it brings to the biopharmaceutical sector a type of dispute most frequently encountered in the litigious ICT sector. The Momenta I case is also distinctive among biopharma patent disputes in that it involved not a branded pharmaceutical manufacturer suing a generic manufacturer for patent infringement (a relatively common occurrence) or a generic manufacturer challenging the validity of a patent on a branded pharmaceutical product, but a patent dispute between two generic biosimilar producers.

Part I of this Essay provides an overview of the recent law and policy that has evolved around the disclosure and non-disclosure of patents within the context of industry standard-setting, primarily in the ICT sector. Part II describes the background and facts of Momenta I then discusses the district court's holding regarding Momenta's alleged failure to disclose the ' 886 patent. This Essay concludes with some observations regarding the implications of Momenta I and the growing importance of collaboratively developed industry standards for the biopharmaceutical sector more broadly.

\section{STANDARDS AND PATENTS}

\section{A. Policies of Standards Development Organizations}

Market participants collaborating within trade associations known as standards-development organizations ("SDO"s) have developed most of the technical interoperability standards in use today. SDOs range from governmentally recognized bodies that address a diverse range of standardization projects (e.g., the International Organization for Standardization ("ISO")), to large, well-established private sector groups that address the standardization needs of major industry segments (e.g., the European Telecommunications Standards Institute ("ETSI"), Internet Engineering Task Force ("IETF"), and Institute for Electrical and Electronics Engineers ("IEEE")) to smaller groups often referred to as "consortia" that focus on one or a handful of related standards (e.g., the HDMI Forum, Bluetooth Special Interest Group, and USB Forum). Because of the significant market benefits that arise from the broad adoption of technical standards, ${ }^{5}$ a high degree of cooperation among

5. See U.S. Dep'T of Justice \& Fed. TRade Comm'N, Antitrust ENFORCEMENT AND INTELLECTUAL PROPERTY RightS: PROMOTING INNOVATION 
competitors has long been tolerated by antitrust and competition law authorities, which might otherwise discourage such large-scale coordination by competitors.

Many of the technological features included in standards can be patented. Such patents are typically obtained by SDO participants that make technical contributions to the standard. However, to the extent that patents cover technologies that are "essential" to the implementation of a standard, concerns can arise. Specifically, there is a risk that the holder of a SEP could emerge after the broad deployment of a standard and then demand excessive rent from all implementers of the standard. Because those implementers may have invested significant amounts of money in the design and production of standardized products, they may incur high, if not prohibitive, costs if they are forced to switch to a new, non-infringing (and nonstandardized) technology. As a result, they may be willing to pay the rent that an SEP holder demands in order to avoid even higher switching costs. This phenomenon has been termed patent or standards "hold-up" and is discussed extensively in the literature. ${ }^{6}$ In addition to harming potential competitors, patent hold-up can have other undesirable market effects, including raising prices for consumers and hindering technological innovation. ${ }^{7}$

To ensure broad access to the standards that they develop and to avoid patent hold-up, many SDOs have adopted policies that fall into two general categories: disclosure policies and licensing policies. ${ }^{8}$

AND COMPETITION $\quad 33-37 \quad$ (2007),

www.usdoj.gov/atr/public/hearings/ip/222655.pdf [https://perma.cc/7UX5-Q4CS] [hereinafter DOJ-FTC Antitrust \& IPR].

6. See Norman V. Siebrasse, Holdup, Holdout and Royalty Stacking: A Review of the Literature, in PATENT REMEDIES AND COMPLEX PRODUCTS: TOWARD A Global Consensus (C. Bradford Biddle et al. eds., 2019); Jorge L. Contreras, Technical Standards, Standards-Setting Organizations and Intellectual Property: A Survey of the Literature (With an Emphasis on Empirical Approaches), in RESEARCH HANDBOOK ON THE ECONOMICS OF INTELlECTUAL PROPERTY LAW, VOL. II Analytical Methods 185, 199-200 (Peter S. Menell \& David Schwartz eds., 2019); DOJ-FTC Antitrust \& IPR, supra note 5, at 35-40.

7. DOJ-FTC Antitrust \& IPR, supra note 5, at 35-40; RENATA B. HESSE \& Frances Marshall, U.S. Antitrust Aspects of FRAND Disputes, in CAMBRIDGE HANDBOOK OF TECHNICAL STANDARDization LAW: COMPETITION, ANTITRUST AND PATENTS 263, 265 (Jorge L. Contreras ed., 2018).

8. See DOJ-FTC Antitrust \& IPR, supra note 5, at 42. These policies are generally considered to be binding on participants in the SDO's activities, though the legal effect of such policies is not always clear. See Jorge L. Contreras, A Market Reliance Theory for FRAND Commitments and Other Patent Pledges, 2015 UTAH 
Disclosure policies require SDO participants to disclose SEPs that they hold to the SDO, generally prior to the approval of a standard. Early disclosure of SEPs enables standards developers to decide whether or not to approve a design that is covered by these SEPs, to choose an alternative, non-infringing technology, to modify a draft standard to eliminate the infringing feature, or to seek licenses to the patented technology. ${ }^{9}$

Licensing policies, on the other hand, require SEP holders to grant standardized product manufacturers the right to use their SEPs on terms that are either royalty-free ("RF") or that bear royalties that are "fair, reasonable and nondiscriminatory" ("FRAND"). These commitments are intended to assure product manufacturers that they will be able to obtain all licenses necessary to manufacture a standardized product. FRAND or RF licensing commitments are required by all SDOs accredited by the American National Standards Institute ("ANSI") and are also widely utilized among other SDOs around the world. ${ }^{10}$

\section{B. Standards Deception as a Defense to Infringement of SEPS}

When a SEP holder violates an SDO's patent disclosure requirements and subsequently seeks to enforce patents against implementers of a standard, the infringing implementer may raise one or more equitable defenses. These defenses include fraud, estoppel, laches, waiver, unclean hands, and implied license. ${ }^{11}$ Each of these defenses is based on the failure of the SEP holder to disclose an SEP necessary for implementation of the collaboratively developed standard. For example, in Stambler v. Diebold, the patent holder (Diebold) allegedly knew for ten years that a proposed standard concerning the activation of automated teller machines infringed its

L. REV 479, 501-17 (2015).

9. See Gil Ohana \& C. Bradford Biddle, The Disclosure of Patents and Licensing Terms in Standards Development, in CAMBRIDGE HANDBOOK OF TECHNICAL STANDARDIZATION LAW: COMPETITION, ANTITRUST AND PATENTS 244, 245 (Jorge L. Contreras ed., 2018); DOJ-FTC Antitrust \& IPR, supra note 5, at 4245.

10. Justus Baron, et al., Making the Rules: The Governance of STANDARD DEVELOPMENT ORGANIZATIONS AND THEIR POLICIES ON INTELLECTUAL PROPERTY RIGHTS 135 (Nikolaus Thumm ed., 2019) [hereinafter JRC Report].

11. See generally, Daryl Lim, Unilateral Conduct and Standards, in CAMBRIDGE HANDBOOK OF TECHNICAL STANDARDIZATION LAW: COMPETITION, ANTITRUST AND PATENTS 47, 56-60 (Jorge L. Contreras ed., 2018). 
patent, yet remained silent "while an entire industry adopted the proposed standard." 12 The court concluded that Diebold's silence was "intentionally misleading" and granted summary judgment for the defendant based on the equitable doctrines of laches and estoppel.

In Wang v. Mitsubishi, ${ }^{13}$ Wang Laboratories proposed a memory chip standard to an SDO known as the Joint Electron Device Engineering Council ("JEDEC"). ${ }^{14}$ During the three years that the JEDEC deliberated the standard, Wang did not disclose that it was seeking patent protection for the chip design. After the JEDEC approved the standard and manufacturers like Mitsubishi began to manufacture chips conforming to the standard, Wang began to enforce its patent. Mitsubishi argued that Wang's conduct over a six-year period gave rise to an implied license under the patent. The jury agreed with Mitsubishi, and both the district court and the Federal Circuit affirmed, pointing to the large amount of evidence that Wang's conduct created an implied license.

In Qualcomm ${ }^{15}{ }^{15}$ the Federal Circuit held that Qualcomm's intentional failure to disclose essential patents covering the H.264 video compression standard to the Joint Video Team (JVT) SDO supported the district court's finding that Qualcomm ceded its right to enforce those patents under the doctrine of implied waiver. ${ }^{16}$ The district court applied the remedy of unenforceability to the patents that Qualcomm failed to disclose. It analogized Qualcomm's inaction to inequitable conduct before the PTO and patent misuse-other forms of conduct resulting in the unenforceability of patent rights. ${ }^{17}$ The Federal Circuit approved the district court's reasoning, recognizing its authority to "give a fair, just, and equitable response reflective of the offending conduct." 18

In each of these cases, the remedy for the SEP holder's failure to disclose patents in violation of an SDO's written or unwritten

12. Stambler v. Diebold, Inc., No. 85 CV 3014, 1988 WL 95479 at 6 (E.D.N.Y. 1988).

13. Wang Labs., Inc. v. Mitsubishi Elecs. Am., Inc., 103 F.3d 1571, 1582 (9th Cir. 1997)

14. JEDEC also makes an appearance in the Rambus disputes, discussed below.

15. Qualcomm Corp. v. Broadcom, Inc., 548 F.3d 1004, 1023 (9th Cir. 2008).

16. Id. at 1022, 1024 (the Federal Circuit also spoke favorably about the doctrine of estoppel, though because of the court's finding regarding waiver, did not need to reach the issue).

17. Id. at $1025-26$.

18. Id. at 1026 . 
policies was to render the undisclosed SEPs unenforceable against products implementing the relevant standards. This remedy is sweeping, as it is generally interpreted to cover not only the particular product manufacturer that raised the defense, but also all implementers of the relevant standard. ${ }^{19}$

\section{Antitrust Remedies for Standards Deception}

In addition to the common law defenses that an infringing implementer can raise, standards deception by a SEP holder can give rise to antitrust claims under the Sherman Act. Section 2 of the Sherman Act makes it unlawful to "monopolize, or attempt to monopolize ... . any part of the trade or commerce among the several States." ${ }^{20}$ To prevail on a claim for monopolization or attempted monopolization, the plaintiff must prove that the defendant had power in the relevant market and willfully sought, acquired, or maintained that power in an unlawful manner. Monopolization claims also require that the defendant had "market power" or the ability to distort competition in a particular product or technology market. Some have argued that standards, once adopted broadly in the marketplace, can confer market power on the holders of patents that is essential to the use of those standards. ${ }^{21}$ The abuse of such market power could thus constitute unlawful monopolization or attempted monopolization.

The Federal Trade Commission ("FTC") has taken the view that an SEP holder's failure to disclose patents essential to industry standards can thus constitute a violation of Section 2. As explained by the FTC, "Exclusionary conduct such as deception may distort the selection of technologies and evade protections designed by [SDOs] to constrain the exercise of monopoly power, with substantial and lasting harm to competition." 22

19. See Jorge L. Contreras, Equity, Antitrust, and the Reemergence of the Patent Unenforceability Remedy, ANTITRUST SOURCE, Nov. 1, 2011, at 1 (discussing remedy of patent unenforceability and other equitable remedies).

20. 15 U.S.C. $\S 2$.

21. Daniel G. Swanson \& William J. Baumol, Reasonable and Nondiscriminatory (RAND) Royalties, Standards Selection, and Control of Market Power, 73 Antitrust L.J. 1, 3-4 (2005); AM. BAR ASSN., HANDBOOK ON ANTITRUST ASPECTS OF STANDARD SETTING 115-17 (2011); Herbert Hovenkamp, FRAND and Antitrust, PENN LAW: LEGAL SCHOLARSHIP REPOSITORY 19-20 (Aug. 2019), https://scholarship.law.upenn.edu/faculty_scholarship/2093/[perma.cc 19FYQ-Z5SK].

22. Rambus, Inc., No. 9302, 2006 WL 2330117, at *18 (F.T.C. Aug. 2, 2006), 
The FTC has brought claims based on deceptive conduct within an SDO principally under its authority to enforce Section 5 of the FTC Act, which prohibits unfair methods of competition. ${ }^{23}$ These cases have included actions against Dell Computer ${ }^{24}$ and Unocal, ${ }^{25}$ both of which involved allegations that an SDO participant deceptively withheld information about patents essential to the practice of a standard and later sought to assert those patents. In each case, this deception was claimed to constitute exclusionary conduct giving rise to a claim for monopolization. The FTC settled its cases against Dell and Unocal, in each case entering a consent order effectively rendering the asserted patents unenforceable. ${ }^{26}$

Perhaps the best-known case of alleged deception within a standards body involved semiconductor memory designer Rambus, Inc. The FTC investigated Rambus for a pattern of allegedly deceptive conduct within JEDEC, including the amendment of its thenundisclosed patent applications to cover current discussions within the SDO. The FTC found that Rambus had engaged in deceptive practices amounting to unfair methods of competition that violated Section 5 of the FTC Act as well as Section 2 of the Sherman Act. ${ }^{27}$

This theory also received support from the Court of Appeals for the Third Circuit in Qualcomm II, ${ }^{28}$ a private antitrust action brought by Broadcom in response to Qualcomm's assertion of previously undisclosed SEPs against it. ${ }^{29}$ Broadcom argued that Qualcomm's intentionally false representations to an SDO known as the Joint Video Group (JVG) violated Section 2 of the Sherman Act, and the court agreed. The court noted that such deception "harms the

rev'd 522 F.3d 456 (D.C. Cir. 2008).

23. 15 U.S.C. $\S 45$.

24. Dell Comput. Corp., 121 F.T.C. 616, 616 (1996).

25. Union Oil Co. of Cal., 2005 WL 6241013 (F.T.C. Jul. 27, 2005). 72.

26. See Lim, supra note 12 at 54-56; Hesse \& Marshall, supra note 8, at 271-

27. Rambus, Inc., 2006 WL 2330117, at *18. The FTC's judgment against Rambus was reversed by the DC Circuit due to the FTC's failure to prove an antitrust injury (harm to competition) (Rambus, Inc. v. FTC, 522 F.3d 456 (D.C. Cir. 2008)). See, generally, Lim, supra note 11, at 51-54; Hesse \& Marshall, supra note 7, at 272-73.

28. Broadcom Corp. v. Qualcomm, Inc., 501 F.3d 297, 311-12 (3d Cir. 2007); see also Hesse \& Marshall, supra note 8, at 274-75.

29. Broadcom Corp. v. Qualcomm, Inc., 501 F.3d 297, 311-12 (3d Cir. 2007) (note that this action was brought roughly in parallel with the action that resulted in the Federal Circuit's 2008 ruling in Qualcomm I, discussed above). 
competitive process by obscuring the costs of including proprietary technology in a standard and increasing the likelihood that patent rights will confer monopoly power on the patent holder." ${ }^{30}$ Despite the specter of such liability, however, the court found that Broadcom lacked standing to bring a claim for monopolization (as it did not yet compete in the relevant market), and that it failed to allege a cognizable antitrust injury. ${ }^{31}$ Thus, the court did not ultimately apply the Sherman Act to Qualcomm's alleged misconduct.

\section{THE ENOXAPARIN CONTROVERSY: A BIOPHARMA STANDARDS DISPUTE}

\section{A. Enoxaparin-Approval and Market Entry}

The anticoagulant properties of the heparin molecule were first described in $1916 .{ }^{32}$ Heparin soon became a common ingredient in treatments for thrombosis, myocardial infarction, and other clotting disorders. In the 1970s, researchers began to experiment with shorter chemical chains derived from the heparin molecule-low molecular weight heparins - which appeared to offer similar efficacy with fewer side effects. ${ }^{33}$ Enoxaparin was the first such low molecular weight heparin to be approved for use in humans. Sanofi-Aventis filed a U.S. patent application covering enoxaparin in 1991, resulting in the issuance of U.S. Pat. No. 5,389,618 in $1995 .{ }^{34}$ Shortly thereafter, Sanofi-Aventis introduced enoxaparin to the U.S. market under the brand name Lovenox. ${ }^{35}$ Lovenox became a blockbuster drug, achieving \$2.7 billion in sales during 2009 alone. $^{36}$

In March 2003, Amphastar Pharmaceuticals, a specialty pharmaceutical manufacturer based in Rancho Cucamonga, California, filed an Abbreviated New Drug Application ("ANDA") with the U.S. Food and Drug Administration ("FDA"), seeking

30. Id.

31. Id.

32. Jie Jack Li \& E.J. Corey, Drug Discovery: Practices, Processes, and Perspectives 189 (2013).

33. Id.

34. U.S. Patent No. 5,389,618 (filed Jul. 16, 1993) (issued Feb. 14, 1995).

35. Complaint I, supra note 1, at 4.

36. Dana A. Elfin, Momenta Battle Over Amphastar Generic Continues, BLOOMBERG (June 20, 2017, 5:37 pm), https://news.bloomberglaw.com/pharmaand-life-sciences/momenta-battle-over-amphastar-generic-continues [perma.cc/L4Z8-9AE9]. 
clearance to market a generic or biosimilar version of enoxaparin. ${ }^{37}$ Amphastar's ANDA contained a declaration challenging SanofiAventis's '618 patent. ${ }^{38}$ As a result, in August 2003, Sanofi-Aventis sued Amphastar for infringement of the ' 618 patent. ${ }^{39}$ That litigation continued for five years and was appealed twice to the Federal Circuit. In May 2008, the Federal Circuit affirmed the district court's decision that the '618 patent was unenforceable (for reasons unrelated to USP and its standards). ${ }^{40}$ The invalidation of Sanofi-Aventis's ' 618 patent cleared the way for entry of generic competitors into the market for enoxaparin subject to FDA approval.

In 2003, the Sandoz division of Novartis entered into a collaboration agreement with Momenta Pharmaceuticals of Cambridge, Massachusetts, relating to the development, manufacture, and commercialization of a generic version of enoxaparin. ${ }^{41}$ Based on characterization work conducted by Momenta, Sandoz filed its own ANDA relating to enoxaparin in August 2005. ${ }^{42}$

Enoxaparin, a broken-down form of the polymer heparin, is a complex biologic pharmaceutical that is manufactured using an organic process rather than traditional chemistry. As a result, it is difficult to determine definitively whether a particular, generic version of enoxaparin is truly "bioequivalent" to the FDA-approved Lovenox. During the pendency of the ANDAs for generic enoxaparin, SanofiAventis contended that enoxaparin could be manufactured only using Sanofi-Aventis's proprietary manufacturing process, and that without it, a generic manufacturer could not guarantee that any substance it

37. Ctr. for Drug Evaluation \& Research, FDA, Application Number: ANDA 076684, CHEMISTRY REVIEWS, 3 (July 25, 2011).

38. Id. at 4. The ANDA process includes what is known as a "Paragraph IV" certification. This regulatory pathway allows a generic drug maker to declare that the patent(s) protecting a brand-name drug are invalid or otherwise unenforceable. The certification immediately forces the issue to litigation in federal court, without requiring the generic manufacturer to enter the market and risk being held liable for patent infringement. See 21 U.S.C. § 355(b)(2)(A)(iv) (2019).

39. Aventis Pharma S.A. v. Amphastar Pharms., Inc., 525 F.3d 1334 (Fed. Cir. 2008). Sanofi-Aventis also sued Teva Pharmaceuticals of Israel, which had also submitted an NDA for the marketing of generic enoxaparin. Aventis Pharma S.A. v. Amphastar Pharms., Inc., 390 F. Supp. 2 d 936 (C.D. Cal. 2005).

40. Aventis, 525 F.3d at 1349.

41. Complaint I, supra note 1, at 6-7.

42. CTR. FOR Drug Evaluation \& RESEARCh, FDA, ApProval PaCKAGE For: APPLICATION NUMBER: ANDA 77-857, 4 (July 23, 2010). 
produced was biologically equivalent to enoxaparin. ${ }^{43}$ Researchers at Momenta, however, identified a unique chemical signature for enoxaparin. On this basis, Momenta contended that one could reliably determine whether a manufactured compound was enoxaparin. As such, Momenta and Sandoz claimed to overcome Sanofi-Aventis's objection that manufacturing enoxaparin would not be possible without using Sanofi-Aventis's proprietary manufacturing process. In 2003, Momenta filed a patent application, claiming several methods of characterizing enoxaparin. The patent was issued in 2009, listing five inventors including Dr. Zachary Shriver, a senior director of research analytics at Momenta.

In July 2010, the FDA approved the Sandoz-Momenta ANDA for generic enoxaparin. ${ }^{44}$ Sandoz began sales of enoxaparin in the U.S. shortly thereafter.

\section{B. The USP and Method 207}

The USP is a non-profit organization founded in 1820. USP produces a substance and preparation monograph for each FDAapproved drug, including biologics such as enoxaparin. ${ }^{45}$ The FDA relies heavily on USP monographs in approving drugs for marketing, and the Federal Food, Drug, and Cosmetic Act provides that approved drugs must meet the strength, quality, and purity requirements set forth by the USP. ${ }^{46}$

In 2006, at the urging of Sanofi-Aventis, USP began to develop a standard for testing the purity of enoxaparin during the manufacturing process. ${ }^{47}$ The standard was based on the presence of a particular " 1,6 anhydro ring" ("AR") structure in $15-25 \%$ of enoxaparin carbohydrate chains. ${ }^{48}$ Sanofi-Aventis proposed to USP a

43. See Transcript of Record: Dr. Kaundinya at 13039, 13041, Momenta Pharm., Inc. v. Amphastar Pharm., Inc., No. 18-1740 (Fed. Cir. appeal docketed March 29, 2018); Larry Bell \& Peter O. Safir, Citizens Petition 1-26, 24 (Feb. 19, 2003).

44. CTR. For Drug Evaluation \& RESEARCH, FDA, APPROVAl PACKAGE For: APPLICATION NuMBER: ANDA 77-857, 4 (July 23, 2010).

45. See U.S. Pharmacopial Convention, Legal Recognition - Standards Categories, https://www.usp.org/about/legal-recognition/standard-categories\# biologics (last visited Feb. 13, 2020) [https://perma.cc/GP5P-3BY7].

46. 21 U.S.C. $\S \S 351(b), 321(\mathrm{j})$.

47. Presumably, Sanofi-Aventis wished to ensure that any generic version of enoxaparin on the market was in fact equivalent to Lovenox.

48. Brief for Appellants at 21, Momenta Pharm., Inc. v. Amphastar Pharm., Inc., 686 F.3d 1348 (2012), 2011 WL 7111556. 
method (which Sanofi-Aventis had allegedly sought to patent) for determining whether the AR structure was present using high performance liquid chromatography ("HPLC"). ${ }^{49}$ Sanofi-Aventis urged USP to adopt its method as an official standard for the manufacture of enoxaparin. This eventually became known as Method 207. ${ }^{50}$

Momenta participated in the deliberations at USP and opposed making Method 207 mandatory for determining the presence of the AR structure. According to Momenta, it developed a superior method for testing for the AR structure using nuclear magnetic resonance. ${ }^{51}$ During a meeting in 2008, USP announced that Sanofi-Aventis allowed its patent application covering its method of detecting the AR structure to lapse. ${ }^{52}$ As there were no other known patents or patent applications covering the proposed method, USP approved Method 207 in $2009 .{ }^{53}$ Yet while the USP monograph for enoxaparin, which became effective in December 2009, contained a requirement that at least $20 \%$ of manufactured enoxaparin contain the AR structure, the monograph did not require that a particular method be used to make that determination.

During its evaluation of Amphastar's ANDA for generic enoxaparin, the FDA issued a Quality Deficiency letter in September 2009, requesting that Amphastar confirm that its manufactured enoxaparin would comply with the requirements of the USP monograph, including presence of the AR structure. ${ }^{54}$ In its response, Amphastar committed that it would ensure that its manufactured enoxaparin complied with the USP monograph requirements, including the presence of the AR structure in the required amounts. ${ }^{55}$ However, neither the FDA nor Amphastar discussed the specific method that would be used to detect the AR structure in Amphastar's

49. Id. at 22 .

50. USP, $<207>$ Test for 1,6-anhydro Derivative for Enoxaparin Sodium.

51. Brief for Plaintiffs-Appellants at 18, Momenta Pharm., Inc. v. Amphastar Pharm., Inc., Fed. Cir. Case No. 18-1740 (filed July 30, 2018) [hereinafter Momenta Appeal Brief].

52. Complaint I, supra note 1 , at 12 .

53. Id.

54. FDA Off. Generic Drugs, Deficiency Letter for ANDA 76-684, Dated Sept. 4, 2009 (Deficiency A2).

55. Amphastar, Quality Amendment for ANDA 76-684 - Enoxaparin Sodium Injection, Sept. 18, 2009 (response to Deficiency A2). 
manufactured enoxaparin. The FDA approved Amphastar's ANDA in September 2011, and Amphastar began sales in the U.S. ${ }^{56}$

Two days later, Momenta brought suit against Amphastar for infringement of the ' 886 patent in the Federal District Court for the District of Massachusetts. ${ }^{57}$ Specifically, Momenta alleged that Amphastar's method for testing manufactured enoxaparin for the AR structure infringed the claims of the patent, which covered numerous testing methods. ${ }^{58}$ After a lengthy set of proceedings, including two separate appeals to the Federal Circuit, ${ }^{59}$ a jury found in 2017 that Amphastar infringed the claims of the ' 886 patent, but that the claims were invalid due to lack of enablement and inadequate written description. ${ }^{60}$ The District Court affirmed the jury's verdict.

In addition, Amphastar raised the equitable defenses of waiver and estoppel, as to which the jury rendered an advisory verdict in favor of Amphastar. ${ }^{61}$ The District Court adopted the jury's advisory

56. Drugs@FDA: FDA-Approved Drugs, U.S. FOOD \& DRUG ADMIN., https://www.accessdata.fda.gov/scripts/cder/daf/index.cfm?event=overview.proces s\&ApplNo=076684 [https://perma.cc/VE7E-5S25] (last visited Feb. 25, 2020).

57. Momenta Pharm., Inc. v. Amphastar Pharm., Inc., 882 F. Supp. 2d 184, 188 (D. Mass. 2011).

58. There are numerous methods that can be used to test enoxaparin for the presence of the AR structure. As noted above, Sanofi-Aventis developed a method based on HPLC which eventually was adopted as USP's Method 207. Momenta Appeal Brief, supra note 52, at 17-18. Momenta first used capillary electrophoresis, and then switched to a superior method based on nuclear magnetic resonance. Momenta Appeal Brief, supra note 52, at 6. And Amphastar developed a disaccharide building block (DBB) procedure for testing enoxaparin, which the FDA approved in 2006 and 2007. Stephen A. Campbell, Telephone Amendment: RE: ANDA 76-684, Enoxaparin Sodium Injection, Amphastar Pharm., (Nov. 2, 2006); Stephen A. Campbell, Telephone Amendment: RE: ANDA 76-684, Enoxaparin Sodium Injection, Amphastar Pharm., (March 29, 2007). At some point after it began to produce generic enoxaparin in September 2011, Amphastar switched from the DBB procedure to Method 207 for testing its product. Momenta alleges that Amphastar strategically switched from the DBB procedure to Method 207 in order to argue that because it was using a method required by the FDA (a requirement that Momenta disputes), it was immunized from suit under 35 U.S.C. $§ 271(\mathrm{e})(1)$ ("It shall not be an act of infringement to make, use, offer to sell, or sell within the United States ... a patented invention ... solely for uses reasonably related to the development and submission of information under a Federal law which regulates the manufacture, use, or sale of drugs...").

59. See Momenta Pharm., Inc. v. Amphastar Pharm., Inc., 686 F.3d 1348 (Fed. Cir. 2012); Momenta Pharm., Inc. v. Amphastar Pharm., Inc., 457 F. App’x. 929 (Fed. Cir. 2011).

60. Momenta Pharm., Inc. v. Amphastar Pharm., Inc., 298 F. Supp. 3d 258, 262 (D. Mass. Feb. 7, 2018).

61. J.E. Macy, Annotation, Nature and Effect of Jury's. Verdict in Equity, 15 A.L.R. 1147 (originally pub. 1945). 
verdict. $^{62}$ The basis for Amphastar's waiver and estoppel was Momenta's failure to disclose the ' 886 patent, allegedly in violation of USP's rules and policies. In 2015, Amphastar brought an antitrust action against Momenta and Sandoz, also in the District of Massachusetts, alleging that they violated the Sherman Act and state antitrust laws as a result of the same failure. ${ }^{63}$

\section{The USP Policies}

USP has a number of written policies that are binding on individuals and firms participating in its standardization work. First, the USP Rules and Procedures govern the conduct of USP's various expert bodies. ${ }^{64}$ Second, the written USP Guidelines govern the submission of proposals for the creation of a new USP monograph. ${ }^{65}$

Amphastar argued that USP's written policies required Dr. Shriver to disclose the existence of Momenta's application for the ' 886 patent to USP prior to approval of the standard, which he did not. Due to this failure, Amphastar alleged that Momenta intentionally violated USP's policies. ${ }^{66}$ In consequence, Amphastar argued that: (1) Momenta waived its right to enforce the ' 886 patent, (2) Momenta was estopped from enforcing the ' 886 patent, and (3) Momenta and Sandoz violated Section 2 of the Sherman Act as well as various state antitrust and competition statutes by "wrongfully acquiring monopoly power by deceiving the USP into adopting a standard which they later claimed was covered by" the " 886 patent. These allegations reflected a typical SDO deception scenario, akin to the facts alleged in cases like Dell, Rambus, and Qualcomm. In each of these cases, the central issue is "the consequence of silence in the face of a duty to disclose patents in a standards-setting organization." 67

62. Momenta I, 298 F. Supp. 3d at 265.

63. See generally Amphastar Pharm., Inc. v. Momenta Pharm., Inc., 297 F. Supp. 3d 222 (D. Mass. 2018).

64. USP Rules and Procedures of the 2005-2010 Council of Experts, U.S. PHARMACOPEIA, http://www.pharmacopeia.cn/v29240/usp29nf24s0_rules-12158.html [https://perma.cc/V3PN-ZL8E] (last visited Nov. 1, 2020).

65. USP Guideline for Submitting Requests for Revision to USP-NF (April 29, 2016), https:/www.usp.org/sites/default/files/usp/document/get-involved/ submission-guidelines/general-information-for-all-submissions.pdf [https://perma.cc/8KJZ-2UYV].

66. Complaint I, supra note 1, at 10-11.

67. Qualcomm Corp. v. Broadcom Inc., 548 F.3d 1004, 1008 (9th Cir. 2008). 
In assessing Momenta's failure to disclose the ' 886 patent, the court considered Momenta's and Dr. Shriver's obligations under USP's written policies. First, under the USP Guidelines, all "Sponsors" of USP technical proposals are requested to disclose "whether any portion of the methods or procedures submitted are subject to patent or other Sponsor-held intellectual property rights." 68 Momenta made no disclosure responsive to this provision. ${ }^{69}$ However, the court noted that the only official "Sponsor" of Method 207 was Sanofi-Aventis. Because Momenta was not listed as a Sponsor of the standard, it had no obligation to disclose its patent under this provision.

Next, Section 2.05 of the USP Rules and Procedures states that no advisory panel member with a "financial or other interest that may conflict, or may appear to conflict, with his or her duties and responsibilities with respect to a particular matter, shall vote on such matter." 70 Dr. Shriver was a member of USP's Heparin Ad Hoc Advisory Panel and, as such, was subject to the Rules and Procedures. Accordingly, Dr. Shriver abstained from voting on the Method 207 standard. ${ }^{71}$ The court agreed that Dr. Shriver's abstention from the Method 207 vote complied with Section 2.05 of the Rules and Procedures.

Finally, Section 2.06(a) of the Rules and Procedures requires that each advisory panel member submits a written statement to USP disclosing his or her employer, sources of research funding, and "other professional or financial interests, including intellectual property rights, that may result in a conflict of interest or the appearance of a conflict of interest." 72 Dr. Shriver submitted such a statement and

68. USP Guideline for Submitting Requests for Revision to USP-NF (April 29, 2016), https://www.usp.org/sites/default/files/usp/document/get-involved/submissi n-guidelines/general-information-for-all-submissions.pdf [https://perma.cc/8KJZ2UYV].

69. Momenta I, 298 F. Supp. 3d at 265.

70. USP Rules and Procedures of the 2005-2010 Council of Experts, U.S. PHARMACOPEIA, http://www.pharmacopeia.cn/v29240/usp29nf24s0_rules-12-158 .html [https://perma.cc/V3PN-ZL8E] (last visited Nov. 1, 2020). The topic of conflicts of interest and their disclosure within scientific and technical bodies has gained significant attention in recent years. See, generally Jorge L. Contreras \& Marc D. Rinehart, Conflicts of Interest and Academic Research in RESEARCH Handbook On Intellectual Property And Technology Transfer Ch. 7, 143-65 (Jacob Rooksby, ed., Edward Elgar, 2020).

71. Momenta Pharm., Inc., 298 F. Supp. at 266.

72. USP Rules and Procedures of the 2005-2010 Council of Experts, U.S. 
accurately identified Momenta as his employer. ${ }^{73}$ The only area in which Dr. Shriver's disclosure may have been wanting was his lack of response to a catch-all provision requiring disclosure of "other professional or financial interests." Conceivably, this provision could have been interpreted to require Dr. Shriver to disclose the Momenta patent on which he was listed as an inventor. However, the court found that, at worst, the USP conflicts of interest policy was ambiguous regarding any affirmative obligation to disclose patents. ${ }^{74}$

\section{Participant Understandings of USP's Disclosure Requirement}

In at least two well-known standards deception cases in the ICT industry, courts have looked beyond the ambiguous language of the relevant SDO policies to find affirmative obligations to disclose SEPs. In Rambus v. Infineon ${ }^{75}$ semiconductor designer Rambus, Inc. was accused, among other things, of committing fraud based on its alleged concealment of patents that were essential to the implementation of a standard developed at JEDEC. The district court found that JEDEC's written policies created no such duty of disclosure. But the court also found, based on the testimony of various JEDEC participants, that even without a written disclosure requirement, SDO participants shared a common understanding that they should disclose patents necessary to practice JEDEC standards. ${ }^{76}$ As such, the court recognized a legal duty to disclose arising from the norms and practices of JEDEC participants. ${ }^{77}$

The Federal Circuit in Qualcomm II also upheld a lower court's recognition of a duty to disclose based on informal expectations and practices of SDO participants, where such a duty was not clearly delineated in the SDO's written policies. The court in Qualcomm II recognized that "[a] duty to speak can arise from a group

PHARMACOPEIA, http://www.pharmacopeia.cn/v29240/usp29nf24s0_rules-12-158 .html [https://perma.cc/V3PN-ZL8E] (last visited Nov. 1, 2020).

73. Zachary Shriver, USP Council of Experts, Expert Committee, and Ad Hoc Advisory Panel Member Conflict of Interest Statement (Feb. 26, 2008) (reproduced in Momenta Appeal Brief, supra note 52, at 16).

74. Momenta Pharm., Inc., 298 F. Supp. at 266 ("This Court finds that the disclosure obligation in the written USP policies is ambiguous").

75. Rambus, Inc. v. Infineon Techs. AG, 318 F.3d 1081 (Fed. Cir. 2003).

76. Id. at 1098 .

77. Notwithstanding the existence of such a duty, Rambus was found not to have violated its obligation to disclose patent applications to JEDEC. Id. at 1105. 
relationship in which the working policy of disclosure of related intellectual property rights [("IPR")] is treated by the group as a whole as imposing an obligation to disclose information in order to support and advance the purposes of the group." 78

Accordingly, the district court in Momenta II considered whether USP participants "understood the policies to include a duty to disclose" patents essential to USP standards, notwithstanding the ambiguity of USP's written policies..$^{79}$ In support of this proposition, Amphastar introduced testimony from at least one former USP employee, who testified that there was a "common understanding" among USP participants that patent disclosures were required.$^{80}$ This witness described a 2008 advisory panel meeting at which a USP employee observed that Sanofi-Aventis, the Sponsor of Method 207, had disclosed a relevant patent. According to the witness, a representative from Momenta then asked USP to request SanofiAventis to abandon the patent before approving the standard, which it ultimately did. ${ }^{81}$ Amphastar argued that all of these facts indicated both an informal expectation among USP participants to disclose patents covering USP standards and that Momenta was aware of this expectation. The court agreed, finding that notwithstanding the absence of an express requirement to disclose patents essential to USP's standards, such an obligation should be implied on the basis of unwritten participant expectations. ${ }^{82}$

\section{E. Waiver}

As noted in Part I, both courts and the FTC have found that a patent holder's deceptive failure to disclose an SEP in violation of an SDO's rules can result in a waiver of the right to enforce the SEP. Given that Momenta had an implicit duty to disclose patents essential to USP's standards that its employees helped to develop, Amphastar argued that Momenta breached that duty by failing to disclose the ' 886 patent or its application. As a result, Amphastar argued that Momenta

78. Qualcomm Corp. v. Broadcom Inc., 548 F.3d 1004, 1008 (9th Cir. 2008) (citing Broadcom Corp v. Qualcomm, Inc., 501 F.3d 297, 311-12 (3d Cir. 2007).

79. Momenta Pharm., Inc., 298 F. Supp. at 266.

80. Id. at 268 .

81. Id. at 267.

82. See id. at 264. 
waived its right to enforce the ' 886 patent against Amphastar and other implementers of Method 207. The district court agreed.

Citing Hynix v. Rambus, the court explained that "implied waiver occurs if the behavior of the patent owner was so inconsistent with an intent to enforce its rights as to induce a reasonable belief that such right has been relinquished." ${ }^{83}$ Finding that Momenta had a duty to disclose the ' 886 patent to USP and that it breached this duty, the court held that Momenta waived its right to enforce the patent against any implementers of Method 207. ${ }^{84}$

\section{F. Equitable Estoppel}

Amphastar also argued that it reasonably and detrimentally relied on Momenta's misleading failure to disclose the '886 patent, which induced Amphastar to make significant investments in manufacturing enoxaparin using Method 207. As a result, Amphastar argued Momenta should be estopped from enforcing the ' 886 patent against it with respect to the use of Method 207. The district court agreed. The court noted that to succeed on a claim for equitable estoppel, the alleged infringer must prove that the patent owner engaged in misleading conduct that resulted in a reasonable inference that the owner did not intend to enforce its patent. ${ }^{85}$ The infringer must then show that it relied on the misleading conduct and that it will be materially prejudiced if the patent holder is permitted to enforce the patent against it. ${ }^{86}$ The court acknowledged that a patent holder's breach of its obligation to disclose a patent to an SSO can constitute misleading conduct in this context and that an infringer's subsequent adoption of the relevant standard can demonstrate reliance. ${ }^{87}$

Applying these principles to the facts alleged in this case, the jury found that Momenta breached its duty to USP through its silence and

83. Momenta Pharm., Inc., 298 F. Supp. at 264 (citing Hynix Semiconductor Inc. v. Rambus Inc., 645 F.3d 1336, 1348 (Fed. Cir. 2011) (quoting Qualcomm Corp. v. Broadcom Inc., 548 F.3d 1004, 1020 (9th Cir. 2008)).

84. Id. at 265. The court limited the unenforceability of the ' 886 patent to processes implementing USP Method 207 only. Because only two of the processes used by Amphastar conformed to Method 207, and Amphastar's DBB process did not, the ' 886 patent was held to be unenforceable as to the two procedures that conformed to the standard, but not to DBB. Id. at 270 .

85. Id. at 269.

86. Id.

87. Id. 
that Amphastar detrimentally relied on Momenta's silence in practicing Method 207. ${ }^{88}$ Accordingly, the district court held that Momenta was estopped from enforcing the '886 patent against Amphastar with respect to Method 207. ${ }^{89}$

\section{G. Antitrust Claims}

In addition to raising defenses of waiver and estoppel in the patent infringement suit brought by Momenta, Amphastar brought a separate action in September 2015 charging Momenta and Sandoz with violations of the Sherman Act and California antitrust and competition law. ${ }^{90}$ These claims were also based on Momenta's alleged failure to disclose the ' 886 patent in violation of USP's policies. ${ }^{91}$ Amphastar argued that Momenta "wrongfully acquir[ed] monopoly power by deceiving the USP into adopting" Method 207. This conduct, Amphastar alleged, both improperly excluded Amphastar from the market for generic enoxaparin and drove up the price of generic enoxaparin by billions of dollars. ${ }^{92}$

In denying Momenta's motion to dismiss, the court again cited Qualcomm II, particularly noting that "[d]eception in a consensusdriven private standard-setting environment harms the competitive process by obscuring the costs of including proprietary technology in a standard and increasing the likelihood that patent rights will confer market power on the patent holder." 93 Because Amphastar alleged such conduct, the court held that it articulated a cognizable claim for monopolization under the Sherman Act that survived Momenta's motion to dismiss. ${ }^{94}$

In addition, one month after the initiation of Amphastar's antitrust suit, a group of plaintiffs led by Nashville General Hospital brought an antitrust class action suit against Momenta and Sandoz in

88. Id. at $269-70$.

89. Id. at 270 .

90. Amphastar filed this suit in the Central District of California in September 2015. Amphastar Pharm., Inc. v. Momenta Pharm., Inc., 5:15-cv-01914 (C.D. Cal. filed Sept. 17, 2015). The case was transferred to the District of Massachusetts in January 2016. Amphastar Pharm., Inc. v. Momenta Pharm., Inc., 297 F. Supp. 3d 222, 227 (D. Mass. 2018).

91. Complaint I, supra note 1, at 10-13.

92. Id. at 19.

93. Amphastar Pharm., Inc., 297 F. Supp. at 230.

94. See id. 
the U.S. District Court for the Middle District of Tennessee. ${ }^{95}$ The plaintiffs, consisting of hospitals, HMOs, and other healthcare payors, alleged that Momenta's and Sandoz's actions delayed Amphastar's entry into the market for generic enoxaparin, resulting in elevated prices for the drug. The plaintiffs alleged violations of both Sections 1 and 2 of the Sherman Act.

\section{H. Appeal and Settlement}

In April 2018, Momenta and Sandoz petitioned the district court to certify an interlocutory appeal to the First Circuit for certain antitrust questions raised in their motion to dismiss. ${ }^{96}$ The District Court denied the motion in June. ${ }^{97}$ Momenta and Sandoz then appealed the district court's decisions on waiver and estoppel to the Federal Circuit. ${ }^{98}$ But in June 2019, prior to oral argument, the parties settled their dispute. Under the terms of a confidential settlement agreement, Momenta and Sandoz paid Amphastar \$59.9 million and dismissed all pending litigation among the parties. ${ }^{99}$ Momenta and Sandoz separately settled the Tennessee antitrust class action in December 2019, with Momenta agreeing to pay \$35 million and

95. See Complaint, Hosp. Auth. of Metro. Gov't of Nashville v. Momenta Pharm., Inc., 244 F. Supp. 3d 705, 705 (M.D. Tenn. 2017) (No. 3:15-cv-01100).

96. Defendants' Memorandum in Support of Their Motion for Certification of an Interlocutory Appeal at 6, Amphastar Pharm., Inc. v. Momenta Pharm., Inc., Civil Action No. 1:16-cv-10112-NMG (D. Mass., filed Apr. 17, 2018) [hereinafter Momenta Interlocutory Appeal Brief]. A district court may certify an otherwise nonappealable order (e.g., an order on a motion to dismiss) for interlocutory review by the relevant appellate court if the order involves "a controlling question of law as to which there are grounds for a substantial difference of opinion and an immediate appeal would materially advance the ultimate termination of the litigation". 28 U.S.C. § 1292(b).

97. Memorandum and Order, Amphastar Pharm., Inc. v. Momenta Pharm., Inc., 16-10112-NMG (D. Mass., Jun. 1, 2018) [hereinafter Denial of Interlocutory Appeal].

98. Momenta Appeal Brief, supra note 52 at 17.

99. Amphastar Pharmaceuticals, Inc. Announces Settlement in Litigation with Momenta and Sandoz, GlobE NEWS WIRE (June 19, 2019, 6:00 AM), https://www.globenewswire.com/news-

release/2019/06/19/1871001/0/en/Amphastar-Pharmaceuticals-Inc-Announces-

Settlement-in-Litigation-with-Momenta-and-Sandoz.html.

[https://perma.cc/3ZDV-WPWW]. Unlike so-called "reverse payment settlements" in the pharmaceutical sector (see FTC v. Actavis, Inc., 570 U.S. 136 (2013)), Momenta and Sandoz's payment to Amphastar was in settlement of Amphastar's antitrust claims against them, Amphastar did not agree to withdraw challenges to Momenta's patent (as the patent was previously rendered unenforceable by the court), and Amphastar did not agree to stop selling generic enoxaparin. 
Sandoz agreeing to pay $\$ 85$ million, to the plaintiffs and their counsel. ${ }^{100}$

\section{IMPLICATIONS OF MOMENTA V. AMPHASTAR-HOW WILL BIOPHARMA FARE IN THE STANDARDS WARS?}

The district court decision in Momenta II was the first to apply the patent nondisclosure and deception principles established in ICT standardization cases to parties in the biopharmaceuticals sector. While there are notable similarities between the facts alleged in Momenta I and those in earlier ICT cases like Wang, Stambler, Qualcomm, and the series of cases in involving Rambus, there are significant differences as well. Momenta raised several of these differences in its briefing to the Federal Circuit, but because the parties settled their dispute prior to consideration by the Federal Circuit, the degree to which these differences might have been persuasive to the court is unknown. Nevertheless, it is worth considering some of these distinctions and the degree to which the patent nondisclosure and deception principles that evolved in the ICT industry are apposite to standardization at USP and in the biopharma sector more broadly.

\section{A. Is USP an SDO?}

Momenta argued in its appellate brief that USP differs significantly from the computer and telecommunications SDOs around which the principles of standards deception and nondisclosure were first developed.

USP is an independent, scientific organization that sets formulary standards for drugs sold in the United States. It is not a "standard-setting" body like those previously addressed by this Court: USP is not a consortium of industry competitors setting technical requirements needed for different products to interoperate. Rather, USP produces monographs describing the attributes of drugs; the monographs may be incorporated into requirements set by the FDA. USP's monographs are

100. Mike Leonard, Momenta, Sandoz Get Preliminary OK for Lovenox Class Settlement, BLOOMBERG LAW (Jan. 3, 2020), https://news.bloomberglaw.com/mergers-and-antitrust/momenta-sandoz-getpreliminary-ok-for-lovenox-class-settlement. 
produced by staff scientists, with input from eminent scientists who volunteer on advisory panels and others, including drug companies. ${ }^{101}$

In the above description, Momenta points out two principal areas in which USP is unlike ICT-based SDOs: its organizational structure and the nature of its standards. Each of these are considered below.

\section{SDO Structural Issues}

It is true that the technical work of many ICT-based SDOs is performed largely by volunteer representatives of the SDO's membership - usually companies interested in the standards under development - and the SDO's staff plays a predominantly administrative and coordinating role. ${ }^{102}$ However, this allocation of responsibility varies from SDO to SDO, and some SDOs in the ICT sector have hundreds of professional staff members. ${ }^{103}$

Moreover, in Unocal, the FTC brought an enforcement action against Unocal regarding its failure to disclose relevant patents to the California Air Resources Board (“CARB”). ${ }^{104}$ CARB, a government agency, developed regulations and standards governing the composition of low-emissions gasoline. Unocal participated in CARB's public rulemaking proceedings, making various proposals and representations, while at the same time withholding information about several patent applications that Unocal filed on gasoline technologies under consideration by CARB. The fact that CARB was not an industry association typical of the ICT sector did not deter the FTC from condemning Unocal's allegedly deceptive conduct. Rather, the FTC focused on Unocal's "anticompetitive and exclusionary acts and practices" that constituted "unfair methods of competition" in violation of Section 5 of the FTC Act. ${ }^{105}$ Unocal's conduct, the FTC alleged, caused substantial harm to competition and consumers. ${ }^{106}$ The

101. Momenta Appeal Brief, supra note 52, at 14; see also id. at 4 ("unlike the standard-setting organization in Qualcomm, whose members were industry competitors, USP is an independent, scientific organization.").

102. See generally, JRC Report, supra note 10, at 91-92.

103. Id.

104. Union Oil Co. of Cal., 2005 WL 6241013 (F.T.C. Jul. 27, 2005).

105. Complaint at 20, In re Union Oil Co. of Cal., F.T.C. Docket No. 9305 (filed Mar. 4, 2003).

106. Id. at 19. 
organizational structure of CARB, on the other hand, seems to have had little relevance to the FTC's analysis of Unocal's conduct.

The same can be said for those cases involving SDOs in the ICT sector. In Wang, Stambler, Dell, Qualcomm, and Rambus, the nature of the SDO had little bearing on the alleged conduct of the patent holder and was scarcely discussed. Rather, the courts and agencies considering these cases, whether under equitable defenses to infringement or affirmative theories of antitrust liability, emphasized the unilateral conduct of the patent holder in the face of a commitment to disclose SEPs to the SDO. ${ }^{107}$ Accordingly, it does not seem that structural differences between USP and ICT-based SDOs should play much, if any, role in analyzing Momenta's conduct with respect to non-disclosure of its patents.

\section{Nature of the Standards}

Momenta also points out that the standards developed by USP are "monographs describing the attributes of drugs," rather than "technical requirements needed for different products to interoperate." 108 While this description is itself somewhat inaccurate, as USP's Method 207 described a method for testing the purity of a compound rather than any particular attribute of the compound, Momenta is correct that USP's standards differ from ICT-based standards that seek to enable product interoperability. Yet this distinction does not seem meaningful in the context of Momenta's alleged failure to disclose the '886 Patent. If Momenta's actions harmed competitors like Amphastar (by inducing them to use an infringing method when testing the purity of enoxaparin) or hospitals and healthcare payors (by reducing competition and thus raising the price of generic enoxaparin), then the fact that the standard related to a testing method rather than product interoperability is largely irrelevant. In other words, violating SDO processes for developing testing standards can be just as harmful to competition as violating

107. Of course, the character of ICT-based SDOs as associations of competitors is highly relevant in cases charging the SDO or its members with collusion or other concerted action. See, e.g., George S. Cary \& Daniel P. Culley, Concerted Action in Standard-Setting, in CAMBRIDGE HANDBOOK OF TECHNICAL STANDARDIZATION LAW: Competition, ANTITRUST AND PATENTS 61 (Jorge L. Contreras ed., 2018). But allegations of collusion at the SDO level played no part in Momenta.

108. Momenta Appeal Brief, supra note 52, at 14. 
SDO processes for developing interoperability standards. The FTC's reasoning in Unocal supports this conclusion as the relevant CARB standard related to the chemical composition of reduced emission gasoline. The standard did not pertain to product interoperability, yet Unocal's deceptive concealment of its patents nevertheless resulted in competitive and consumer harm. Accordingly, the nature of USP's standards does not seem particularly relevant to the analysis of Momenta's conduct.

\section{B. Was Method 207 Mandatory?}

In its appellate briefing, Momenta also emphasized that Method 207 was not "mandatory" and argued that Amphastar's equitable defenses should not apply to a non-mandatory standard. ${ }^{109}$ There is clearly some debate regarding whether, as a factual matter, the FDA mandated Amphastar's use of Method 207. According to the district court, "the jury apparently found credible the testimony of Amphastar's witnesses...that Amphastar used the revised [AR testing] procedure in reliance on [Method 207] and was required by the FDA to do so." 110 Amphastar emphasized this point in its appellate brief, arguing that "the FDA required Amphastar to use Method [207] and following the FDA's requirements is not optional."111

Yet it is not clear from the record that this was actually the case. As Momenta points out, the USP monograph on enoxaparin specified the required AR structure to identify the compound but did not specify a particular testing methodology to detect the AR structure. The FDA, in an amicus brief that it filed in an earlier phase of this case, explained that "to satisfy the [FDA] batch-testing requirement, a manufacturer has considerable latitude to employ any test protocol that meets the requirements specific to FDA's approval of that drug, provided that the accuracy, sensitivity, specificity, and reproducibility

109. Id. at 51-54 (alleging that non-mandatory nature of Method 207 was also a linchpin of Momenta's and Sandoz's request for interlocutory appeal of the District Court's denial of their Motion to Dismiss Amphastar's antitrust suit); Momenta Interlocutory Appeal Brief, supra note 96.

110. Momenta Pharm., Inc. v. Amphastar Pharm., Inc., 298 F. Supp. 3d 258, 270 (D. Mass. Feb. 7, 2018).

111. Brief for Defendants-Appellants at 55, Momenta Pharm., Inc. v. Amphastar Pharm., Inc., Fed. Cir. Case No. 18-1740 (filed Sept. 21, 2018) [hereinafter Amphastar Appeal Brief]. 
of test methods employed by the firm are established and documented." 112

USP's Method 207 does describe a particular testing process for detecting the AR structure in manufactured enoxaparin, but this was not the only known testing process for the AR structure, and the testing process was not part of the USP enoxaparin monograph. In fact, Momenta and Sandoz used a different testing process for their manufactured enoxaparin, and even Amphastar used a process other than Method 207 in some cases. ${ }^{113}$ Momenta argued that while the FDA required that Amphastar comply with the USP monograph on enoxaparin, and thus to test for the AR structure, the monograph did not specify how that testing was to be accomplished. ${ }^{114}$

While the FDA was not explicit about the method for testing generic enoxaparin, there is some ambiguity regarding the degree to which USP requires the use of Method 207. Method 207 itself states, "The following procedure is used to determine the levels of [AR structures] in enoxaparin sodium. [NOTE-The test...is conducted only where specified in the individual monograph]."115

This language implies that Method 207 is the way to test for the AR structure in enoxaparin (as testing is required by the enoxaparin monograph), not merely $a$ way to test it. Moreover, Method 207 is included as part of USP's National Formulary, ${ }^{116}$ and the Food, Drug, and Cosmetics Act explicitly requires that the strength, quality, and purity of approved drugs be tested "in accordance with the tests or methods of assay set forth in [the relevant] compendium" (in this case, the USP National Formulary). ${ }^{117}$ There is thus a reasonable case to be made that the use of Method 207 was mandatory, at least to some degree.

But even if the use of Method 207 was not mandatory, it is not clear that this relieves Momenta of liability under relevant doctrines pertaining to patent disclosure in standard-setting. Admittedly, some technical standards that have been subject to disputes regarding patent

112. Corrected Brief for the United States as Amicus Curiae at 6, Momenta Pharm., Inc. v. Teva Pharm. USA Inc., (Filed Jul. 17. 2015) (quoting 21 C.F.R. $\S$ 211.165(e)).

113. Momenta Appeal Brief, supra note 52, at 53-54.

114. Id. at $53-54$.

115. Method 207, supra note 50, at 1.

116. $I d$.

117. 21 U.S.C. $\S 351(b), \S 321(j)$. 
disclosure are mandated by government edict. One example is the standard for low emissions gasoline adopted by CARB, which was at issue in Unocal. However, in the ICT sector, most technical standards are voluntary. That is, firms are not required, either by government regulation or SDO rules, to use them. ${ }^{118}$ The success or failure of interoperability standards is thus dictated largely by market forces rather than government edict, and the landscape is littered with abandoned standards that never achieved market success (e.g., who remembers WIMAX, Firewire, or HD-DVD?). In fact, the voluntary nature of collaboratively developed standards (at least before the market broadly adopts them) is one of the principal safety mechanisms that ensures that SDOs do not exert anticompetitive market power by forcing participants to adopt their standards. ${ }^{119}$

Nevertheless, Momenta attempts to recharacterize the voluntary nature of most ICT standards, reasoning that they are "effectively mandatory" - an industry participant must practice them in order to compete effectively. ${ }^{120}$ Momenta argues that the threat of patent hold-up and the accompanying anticompetitive effects occur only when the adoption of a standard is mandatory (or "effectively" mandatory). But because Method 207 was not mandatory, Momenta argues it could not hold the industry "hostage" as Qualcomm and others allegedly did in the ICT standards deception cases. Momenta argues that failing to disclose patents covering optional standards "creates no trap because industry participants can choose alternate technology." 121

Momenta's arguments here are worth considering in some detail, as they address the fundamental rationale behind liability for standards deception. Clearly, when a technology is not standardized, a patent holder is free (subject to generally-applicable antitrust laws) to assert its patents covering that technology in any manner, whether to extract whatever royalties the market will bear or to prevent others

118. See David J. Teece \& Edward F. Sherry, Standards Setting and Antitrust, 87 MinN. L. ReV. 1913, 1919-20 (2003); ABA CoMm. On TECH. STANDARDIZATION, StandardiZATIOn DEVElopment Patent Policy Manual IX, (Jorge L. Contreras ed., 2007) [hereinafter ABA Standards Manual].

119. See Raymond T. Nimmer, Technical Standards Setting Organizations \& Competition: A Case for Deference to Markets, WASHINGTON LEGAL FOUNDATION CRITICAL LEGAL ISSUES WorkING PAPER SERIES No. 155 at 9-10 (2008).

120. Momenta Appeal Brief, supra note 52, at 52.

121. Id. at $52-53$. 
from competing with respect to patented features. If a product manufacturer does not wish to pay the required royalty, or fears an injunction from the patent holder, then the manufacturer is free to use an alternate, non-infringing technology.

When the patented technology is standardized, however, different considerations come into play. A standard is intended to be broadly adopted, and an SDO imposes a patent disclosure policy to promote the broad adoption of its standards. Market participants are encouraged to adopt such standards with the expectation that all SEPs have been disclosed. On that basis, they can make investments in manufacturing, design, marketing, and the like based on the standardized technology, whether or not it is formally mandated by law or SDO rules. When a patent holder emerges later with a previously undisclosed SEP, these investments can be upset.

In the case of enoxaparin, it appears that several methods of conducting AR structure testing were available, and several noninfringing alternatives were in use by Momenta, Sandoz, and Amphastar. If Amphastar truly had no obligation to use Method 207, then the only harm suffered by Amphastar from Momenta's late disclosure of the ' 886 patent would have been its cost of switching to an alternate, non-infringing testing method. Nevertheless, those switching costs may have been non-negligible. In addition, in October 2011 Momenta obtained a preliminary injunction preventing Amphastar from selling generic enoxaparin on the basis of the ' 886 patent. $^{122}$ Though the Federal Circuit stayed the injunction four months later, Amphastar's sales of generic enoxaparin remained limited due to the ongoing litigation. ${ }^{123}$ The class action plaintiffs in Tennessee claimed that Momenta and Sandoz reaped hundreds of millions of dollars in wrongful overcharges as a result of Momenta's concealment of its patent. ${ }^{124}$ These considerations all point to some monetary remedy that might have been available to Momenta and the class action plaintiffs, which might have been borne out by the multimillion dollar settlements that Momenta reached with each of them.

122. Momenta Pharm., Inc. v. Amphastar Pharm., Inc., 298 F. Supp. 3d 258, 262 (D. Mass. Feb. 7, 2018).

123. Amended Complaint at 19-21, Amphastar Pharm., Inc. et. al. v. Momenta Pharm., Inc., No. 5:15-cv-01914 (C.D. Cal. filed Dec. 16, 2015) [hereinafter Amended Complaint].

124. Id. at 2 . 
However, the district court's ruling in Momenta II did not award monetary relief to Amphastar. Rather, the district court rendered Momenta's '886 patent unenforceable against the practice of Method 207 (i.e., Momenta's waiver of its right to enforce the patent and its estoppel from doing so). And, presumably, this ruling would extend not only to Amphastar, but also to other producers of generic enoxaparin (e.g., Teva), and most likely stands even after the parties' settlement of their various suits. As such, the unenforceability remedy can be seen as even more potent than monetary relief. ${ }^{125}$ And it is distinctly unrelated to the harm suffered by implementers of the relevant standard. Rather, it addresses deceptive conduct by the patent holder in violating the SDO's policies and is imposed to safeguard the integrity of the SDO standardization process, whether or not particular harm can be shown in a given instance. That is, even if Amphastar and the class action plaintiffs were unable to prove any monetary injury arising from Momenta's concealment of the '886 patent, the unenforceability remedy would still be available to punish Momenta for its deceptive conduct. The next sections explore the contours of this liability.

\section{Intent to Trap the Industry}

Momenta argues that even if it was required to disclose the ' 886 patent to USP and failed to do so, the district court should not have imposed the remedy of patent unenforceability because Momenta did not intend to "trap" the industry into using a standard that it had patented. ${ }^{126}$ On the contrary, Momenta actively opposed the adoption of Method 207 at USP. Momenta argues that it "sought to prevent USP from locking Momenta and anyone else into using Method 207 so that industry would be free to use newer, more accurate methods." ${ }^{127}$ Momenta contrasts its behavior with that of Qualcomm in Qualcomm $I$, observing that "Qualcomm had engaged in a carefully orchestrated plan with the deadly determination of holding hostage the entire

125. See Jorge L. Contreras, Equity, Antitrust, and the Reemergence of the Patent Unenforceability Remedy, ANTITRUST SOURCE, Nov. 1, 2011, at 5-7 (discussing remedy of patent unenforceability and other equitable remedies).

126. Momenta Appeal Brief, supra note 48, at 55-56.

127. Id. at 56 (possibly contradicting Momenta's prior argument that Method 207 was not mandatory). 
industry desiring to practice the...standard." ${ }^{128}$ Momenta's behavior, on the other hand, was "the very opposite of a patent holder intentionally trapping an industry into using its patent." 129

Momenta's arguments are worth considering here. In most standards deception cases, the patent holder allegedly urged the SDO to adopt the standard-portions of which it had surreptitiously patented. If Momenta's assertions are taken at face value, then its opposition to Method 207 would indeed suggest a less abusive pattern of conduct than that challenged in cases like Qualcomm I. ${ }^{130}$

Nevertheless, Method 207 was ultimately adopted by USP as a standard, and Momenta did fail to disclose the '886 patent. If there were no penalty for such omissions, the effectiveness of SDO rules requiring disclosure would be severely limited.

This is perhaps the reason that the FTC, in its case against Dell Computer, adopted what could be termed a strict liability standard for failure to disclose SEPs to an SDO. ${ }^{131}$ In her dissenting statement, Commissioner Mary L. Azcuenaga outlines the relative blamelessness of Dell in dealing with the Video Electronics Standards Association ("VESA"):

Nothing in the limited information available to the Commission suggests that Dell had any greater role in the development and promulgation of the VESA VLbus standard than that described in the minimal factual allegations in the complaint. For example, the complaint does not allege that Dell proposed or sponsored the standard, that Dell urged others to vote for the standard, that Dell employees participated in drafting the standard, that Dell employees were present, in person or online, during the committee drafting sessions, that Dell steered the VESA committee toward adopting a standard that

128. Id. at 50 (quoting Qualcomm Corp. v. Broadcom Inc., 548 F.3d 1004, 100910 (9th Cir. 2008) (internal quotation marks omitted)).

129. Id. at 56 .

130. Even Qualcomm disputed the characterization of its behavior, arguing that "[e]ven if a duty to disclose had been breached, this breach is best explained as negligence, oversight, or thoughtlessness, which does not create a waiver." Qualcomm Corp. v. Broadcom Inc., 548 F.3d 1004, 1020 (9th Cir. 2008).

131. See Dell Computer Corp., Dissenting Statement of Commissioner Mary L. Azcuenaga, 121 F.T.C. 627, 630 (1996). 
incorporated Dell technology, or that Dell had any hand whatsoever in shaping the standard. The sole act for which Dell is charged with a violation of law is that Dell's voting representative, in voting to adopt the standard, signed a certification that to the best of his knowledge, the proposed standard did not infringe on any relevant intellectual property. ${ }^{132}$

Nevertheless, the FTC held that because Dell, as an entity, must have been aware of its patent covering the VL-Bus standard and because it did not disclose that patent to VESA, Dell lost the ability to enforce that patent against others. "[W]here Dell failed to act in good faith to identify and disclose patent conflicts-enforcement action is appropriate to prevent harm to competition and consumers." 133

Momenta, for its part, appears to have had an even greater awareness of its relevant SEP than the Dell engineer who certified that he was unaware of Dell's pending patents covering the VL-bus standard. At least Dr. Shriver, who made representations to USP, was listed as an inventor on the ' 886 patent and could hardly claim to have been unaware of it. Accordingly, the district court's holding that the '886 patent was unenforceable does not go even so far as the FTC did in Dell.

Likewise, there is little basis for Momenta's argument that only intentional scheming to trap the industry is required to warrant a remedy of patent unenforceability. Without this remedy, the incentives to comply with SDO disclosure policies would be significantly weakened.

\section{Reliance}

The district court in Momenta II also adopted the jury's advisory verdict finding that Momenta should be equitably estopped from enforcing the ' 886 patent against Amphastar. ${ }^{134}$ In analyzing this claim, the court first recited the three general elements required for equitable estoppel: 1) misleading conduct resulting in a reasonable

132. Id. at 628 .

133. Dell Comput. Corp., 121 F.T.C. 616, 624 (1996). The FTC declined to address the prospect of liability for truly "inadvertent" failures to disclose patent rights; $I d$. at 625 .

134. Momenta Pharm., Inc. v. Amphastar Pharm., Inc., 298 F. Supp. 3d 258, 270 (D. Mass. Feb. 7, 2018). 
inference of non-enforcement, 2) reliance, and 3) material prejudice resulting from the patent owner's assertion. ${ }^{135}$ The findings, discussed above - that Momenta failed to disclose the ' 886 patent as required by USP's rules - support a finding of misleading conduct by Momenta. Likewise, material prejudice is not difficult to find based on Amphastar's alleged investment in the conduct of Method 207. ${ }^{136}$

Proving reliance, however, was "a closer question that was vigorously disputed at trial." 137 Ultimately, the district court deferred to the jury's evaluation of witness credibility in making this determination. ${ }^{138}$ In its appellate brief, Momenta refuted Amphastar's reliance arguments on several grounds. First, Momenta noted that Amphastar could not have relied on any statement or action of Momenta, because the parties had no dealings until this litigation. ${ }^{139}$ Second, Momenta objected to the district court's "substituting Amphastar's supposed reliance on USP in place of any reliance on statements or conduct by Momenta." 140 Even if such reliance could estop Momenta from asserting its patent, Momenta argued that Amphastar had no relationship or communication with USP either. Finally, Momenta points out that Amphastar did not start using Method 207 until 2011 after Momenta sued Amphastar for patent infringement. Accordingly, Amphastar could not have relied on Momenta's alleged deception in deciding to use Method 207. ${ }^{141}$

Clearly, the facts in this case are complex, and the district court might have been justified in leaving such a fraught factual determination to the jury. Yet the difficulty of proving reliance in equitable estoppel cases has raised doubts regarding the general effectiveness of this doctrine in the standards-setting context. ${ }^{142}$ To

135. Id. at 269 (citing Radio Sys. Corp. v. Lalor, 709 F.3d 1124, 1130 (Fed. Cir. 2013)).

136. Id. at 270 .

137. Id. at 269 .

138. Id. at 270 .

139. Momenta Appeal Brief, supra note 52, at 69.

140. Id.

141. Id. at 69-71.

142. See Contreras, supra note 8, at 522-23 ("equitable estoppel is not an ideal theoretical framework for the general enforcement of [standards-related patent commitments]"); George S. Cary et al., The Case for Antitrust Law to Police the Patent Holdup Problem in Standard Setting, 77 ANTITRUST L.J. 913, 939 (2011) (both the reliance and material prejudice elements of equitable estoppel may be difficult to prove in the standards context); Robert P. Merges \& Jeffrey M. Kuhn, An Estoppel Doctrine for Patented Standards, 97 CALIF. L. REV. 1, 39 (2009) 
address the potential mismatch between equitable estoppel and the misfeasance that can arise from deception in the standardsdevelopment context, the Author has previously proposed that courts consider a modified form of promissory estoppel in which the implementer of a standardized product need not prove actual reliance on any statement or action of the defaulting patent holder, but that the implementer need only to prove that the patent holder participated in an industry-wide standardization activity intended to produce a broadly adopted standard ("market reliance"). ${ }^{143}$ This approach would alleviate many of the evidentiary challenges presented by cases such as Momenta.

\section{E. Antitrust Claims}

While Amphastar's antitrust claims against Momenta and Sandoz survived the defendants' motion to dismiss, those claims were never fully adjudicated, either in the antitrust suit brought by Amphastar or the class action filed in Tennessee. ${ }^{144}$ In denying Momenta's motion to dismiss and its request for certification of an interlocutory appeal, the court noted primarily that Amphastar stated legally-cognizable claims, the disposition of which would require the introduction of factual evidence and the application of the law to those facts. ${ }^{145}$ Yet the cases were settled prior to the adjudication of factual questions.

That being said, it is worth considering the two antitrust issues as to which Momenta requested certification. First, building on its earlier argument that Method 207 was not mandatory, ${ }^{146}$ Momenta claims that USP's adoption of Method 207 was merely a "certification" of Method 207 and that mere "product certification"

("equitable estoppel has inherent limitations that preclude its effectiveness against snake-in-the-grass and bait-and-switch tactics. The primary defects are its requirements of: (1) misrepresentation by the patentee to the infringer; (2) reasonable reliance on those promises by the infringer; and (3) material reliance"). But see Henry E. Smith, Property as Platform: Coordinating Standards for Technological Innovation, 9 J. COMPETITION L. \& ECON. 1057, 1086 (2013) (describing equitable estoppel as a viable "anti-opportunism safety valve" for standard setting).

143. Contreras, supra note 8, at 542-43.

144. See Section II.H, supra (discussing settlement of antitrust cases).

145. Momenta Interlocutory Appeal Brief, supra note 96, at 369.

146. See supra Section III.B (Momenta's argument that Method 207 was not mandatory). 
lacks the exclusionary effect necessary for an antitrust violation. ${ }^{147}$ That is, while USP's endorsement of Method 207 demonstrates that it was an acceptable method for testing enoxaparin, alternative testing methods exist, including alternative methods used by Amphastar itself. Thus, even if Momenta's failure to disclose its patent covering Method 207 violated USP's rules and procedures, ${ }^{148}$ this conduct should not give rise to antitrust liability unless it resulted in the exclusion of other competing methods. And because Momenta's failure to disclose clearly did not result in such exclusion, no antitrust liability should attach to that failure. Accordingly, Momenta asked the court to certify to the First Circuit the question "whether antitrust liability requires that the alleged misconduct cause the standardsetting organization to eliminate alternative technologies." 149

Momenta's second proposed question for interlocutory appeal was "whether antitrust plaintiffs must allege that the standard-setting organization would not have adopted the patented technology but for the defendant's misrepresentation." 150 This question has roots in the DC Circuit's rejection of antitrust claims against Rambus, Inc. ${ }^{151}$ In Rambus v. FTC, the court found that while Rambus may have engaged in unethical behavior, the plaintiffs failed to prove that the relevant SDO would not have adopted Rambus's technology but for its failure to disclose its patents as required by the SDO's rules. ${ }^{152}$

Both of these proposed questions are based on the premise that even if Momenta breached USP's rules by failing to disclose the ' 886 patent, that breach should not constitute a violation of the antitrust laws because "antitrust remedies are rarely appropriate to regulate standard-setting conduct." 153 Momenta's bid to limit the reach of the antitrust laws in the context of standard-setting reflects a larger debate in the standardization world. Among other authorities, Momenta quotes two separate speeches by Makan Delrahim, Assistant Attorney

147. Momenta Interlocutory Appeal Brief, supra note 96, at 369.

148. In this regard, Momenta cites various authorities for the proposition that deceptive conduct, and even "acts of pure malice" do not necessarily give rise to antitrust violations. See Momenta Interlocutory Appeal Brief, supra note 96, at 370 (quoting Rambus, 522 F.3d at 464).

149. Momenta Interlocutory Appeal Brief, supra note 96, at 369 (emphasis added).

150. Id. (emphasis added).

151. Rambus, Inc. v. FTC, 522 F.3d 456 (D.C. Cir. 2008).

152. Id. at 466-67.

153. Momenta Interlocutory Appeal Brief, supra note 96, at 6. 
General for the DOJ Antitrust Division, in each of which Mr. Delrahim argues that antitrust remedies should be disfavored in the context of technical standard setting. ${ }^{154}$ Along these lines, the DOJ and like-minded commentators have increasingly argued that single-firm conduct (monopolization) should attract less antitrust scrutiny than collusive behavior by the members of standards bodies. ${ }^{155}$ This shift in emphasis would tend to exonerate allegedly deceptive behavior by firms like Rambus, Qualcomm, and Momenta and instead place greater pressure on measures taken by SDOs to limit the leverage of patent-asserting firms. ${ }^{156}$ And though these issues never reached full adjudication in Momenta, their appearance indicates that the issues at stake in this dispute among generic biopharmaceutical manufacturers are not fundamentally different than those currently litigated in the ICT sector.

\section{F. The Need for Clarity in Biopharma SDO Policies}

Perhaps the most unusual aspect of the Momenta cases is the uncertain foundation upon which the obligation to disclose patents at USP was built. The district court acknowledged that USP's Guidelines (which applied only to Sponsors) did not create a disclosure obligation, and that Momenta's employee, Dr. Shriver, technically complied with the conflict of interest rules set out in USP's Rules and Procedures. ${ }^{157}$ The only source of a disclosure obligation binding on Momenta arose from the conflict of interest form that Dr. Shriver submitted, which asked him to list "other professional or financial

154. See id. at 6 and 9-10 (quoting Makan Delrahim, Good Times, Bad Times, Trust Will Take Us Far: Competition Enforcement and the Relationship Between Washington and Brussels, Remarks as Prepared for the College of Europe, at 8 (Feb. 21, 2018), https://www.justice.gov/opa/speech/file/1036541/download and Makan Delrahim, Take It to the Limit: Respecting Innovation Incentives in the Application of Antitrust Law, Remarks as Prepared for Delivery at USC Gould School of Law, at 9 (Nov. 10, 2017), https://www.justice.gov/opa/speech/file/1010746/download).

155. See Jorge L. Contreras, Taking it to the Limit: Shifting U.S. Antitrust Policy Toward Standards Development, 103 MinN. L. REV. HEADNOTES 66 (Fall 2018) (describing shift in U.S. DOJ policy toward standard setting).

156. See id.; see also Herbert Hovenkamp, Justice Department's New Position on Patents, Standard Setting, and Injunctions, The Regulatory ReVIew, (Jan. 6, 2020), https://www.theregreview.org/2020/01/06/hovenkamp-justice-departmentnew-position-patents-standard-setting-injunctions/ [https://perma.cc/VHL9-

UTQH]; Douglas Melamed \& Carl Shapiro, How Antitrust Law Can Make FRAND Commitments More Effective, 127 YALE L. J. 2110 (2018).

157. See supra Section II.C. 
interests." 158 His failure to list the "886 patent in response to this question gave rise to the "ambiguity" identified by the court and to the subsequent introduction of evidence of the common understanding of participants regarding patent disclosure.

The district court in Momenta II followed the lead of the Federal Circuit in Rambus v. Infineon and Qualcomm I by looking to such common understandings when confronted with ambiguous SDO policy language. In particular, the court focused on USP's insistence that Sanofi-Aventis abandon its own patent covering purity testing for enoxaparin. ${ }^{159}$ That, together with other witness testimony, gave rise to the obligation that the court found for all other expert panel members to disclose patents held by their own companies.

Such a disclosure expectation and obligation may, indeed, have existed at USP. However, it was far from clear. A written policy document that clearly described what patent disclosure obligations, if any, bound the members of USP expert panels would have been preferable. The FTC's 1996 ruling against Dell and the Federal Circuit's 2003 holding in Rambus v. Infineon served as wake-up calls to SDOs in the ICT sector. In particular, the Federal Circuit's sharp critique of the JEDEC patent policy — which the court characterized as suffering from "a staggering lack of defining details" that left SDO participants with only "vaguely defined expectations as to what they believe the policy requires"160_motivated many SDOs to clarify their own policies in this regard. ${ }^{161}$ The result is that many SDOs in the ICT sector increased their patent policies in length and complexity and defined the obligations of SDO participants with a reasonable degree of specificity.

Unfortunately, with a few exceptions, the same degree of evolution has not occurred in the policies of SDOs that operate in the biopharma sector. ${ }^{162}$ USP's Rules and Procedures, as they are

158. Shriver, supra note 73.

159. Momenta Pharm., Inc. v. Amphastar Pharm., Inc., 298 F. Supp. 3d 258, 267 (D. Mass. Feb. 7, 2018).

160. Rambus, Inc. v. Infineon Techs. AG, 318 F.3d 1081 (Fed. Cir. 2003).

161. See, e.g., Contreras, supra note 6, at 27. Shortly after the Infineon decision was released, the American Bar Association initiated a three-year long project to provide drafting guidance to the industry regarding the terms of SDO patent policies. ABA Standards Manual, supra note 118.

162. Notable exceptions include Integrating the Healthcare Enterprise (IHE), which has adopted a robust intellectual property policy addressing trademarks, copyrights and patents, Integrating the Healthcare Enterprise (IHE) International, 
described in Momenta, resemble the conflict of interest policies of scientific journals and funding agencies more than patent policies of technical standards bodies. ${ }^{163}$ To avoid the degree of uncertainty and the resulting disputes that arose in the Momenta cases, USP and other SDOs in the biopharma sector should carefully review their existing patent policies and make any necessary clarifications and amendments to ensure that these policies clearly and unambiguously define the obligations of their participants. ${ }^{164}$ This exercise can produce added clarity that will facilitate the standardization process, avoid unintentional breaches of policy, and, hopefully, thwart those who deliberately wish to abuse the standardization process to their own ends.

\section{CONCLUSION}

Momenta v. Amphastar demonstrates that issues surrounding the acquisition and disclosure of patents claiming standardized technologies have more salience in the biopharma sector than commonly believed. While significant factual uncertainty continues to exist regarding the intentions and obligations of the parties in Momenta, the lack of clarity inherent in USP's policies echoes the ambiguities that plagued SDO policies in the ICT sector two decades ago. As such, standards organizations operating in the biopharma sector should ensure that their policies and procedures are robust enough to delineate clearly the obligations of participants with respect to patents covering standardized technologies. Organizations that participate in biopharma standards-development should heed the

Inc., Principles of Governance - Appendix A: Intellectual Property Agreement (March 14, 2019), and the Global Alliance for Genomics and Health (GA4GH), a group that develops standards for genomic data exchange and storage, which is in the process of developing such policies. Global Alliance for Genomics \& Health, Constitution of the Global Alliance for Genomics and Health, $\S 7$ (v2, Jan. 22, 2018). Most, however, have not. See Contreras \& Thorogood, supra note 4.

163. See Contreras \& Rinehart, supra note 70.

164. In 2008 the author foresaw that SDO intellectual property policy issues could affect the biopharmaceutical industry. See Jorge L. Contreras, Correspondence: Legal Issues in the Development of Biological Research Standards, 26 NATURE BIOTECH. 498, 499 (2008):

To date, the biological sciences have been blissfully free of the standards litigation battles that have plagued the ICT industry. With the increasing adoption of standards by biological researchers, however, these issues will become increasingly relevant. Thus, participants in the biological research field should take care to organize their standards-development efforts carefully and with adequate legal consideration. 
valuable lessons offered by more than three decades of litigation in the technology sector. 